Techniques \& Culture

4 | 1985

Aspects des agricultures insolites de l'Amérique indienne

\title{
Les statuettes en terre cuite d'Ocumicho: La naissance d'un art "traditionnel"
}

\section{Cécile Gouy-Gilbert}

\section{(2) OpenEdition}

Journals

Édition électronique

URL : https://journals.openedition.org/tc/988

DOI : $10.4000 /$ tc. 988

ISSN : 1952-420X

Éditeur

Éditions de l'EHESS

Édition imprimée

Date de publication : 1 février 1985

ISSN : 0248-6016

Référence électronique

Cécile Gouy-Gilbert, « Les statuettes en terre cuite d'Ocumicho : La naissance d'un art "traditionnel" », Techniques \& Culture [En ligne], 4 | 1985, mis en ligne le 26 janvier 2006, consulté le 29 septembre 2022. URL : http://journals.openedition.org/tc/988 ; DOI : https://doi.org/10.4000/tc.988

Ce document a été généré automatiquement le 29 septembre 2022.

Tous droits réservés 


\section{Les statuettes en terre cuite} d'Ocumicho : La naissance d'un art "traditionnel"

Cécile Gouy-Gilbert 